\title{
RESPONSES OF EGG-LAYING PIED FLYCATCHERS TO EXPERIMENTAL CHANGES IN CLUTCH SIZE: A RE-EXAMINATION
}

\author{
Author(s): M. D. Kern , R. J. Cowie , F. M. Slater \\ Source: The Condor, 102(2):428-432. 2000. \\ Published By: Cooper Ornithological Society \\ DOI: http://dx.doi.org/10.1650/0010-5422(2000)102[0428:ROELPF]2.0.CO;2 \\ URL: http://www.bioone.org/doi/full/10.1650/0010-5422\%282000\%29102\%5B0428\%3AROELPF\%5D2.0.CO \\ $\% 3 \mathrm{~B} 2$
}

BioOne (www.bioone.org) is a nonprofit, online aggregation of core research in the biological, ecological, and environmental sciences. BioOne provides a sustainable online platform for over 170 journals and books published by nonprofit societies, associations, museums, institutions, and presses.

Your use of this PDF, the BioOne Web site, and all posted and associated content indicates your acceptance of BioOne's Terms of Use, available at www.bioone.org/page/terms of use.

Usage of BioOne content is strictly limited to personal, educational, and non-commercial use. Commercial inquiries or rights and permissions requests should be directed to the individual publisher as copyright holder. 
The Condor 102:428-432

(C) The Cooper Ornithological Society 2000

\title{
RESPONSES OF EGG-LAYING PIED FLYCATCHERS TO EXPERIMENTAL CHANGES IN CLUTCH SIZE: A RE-EXAMINATION ${ }^{1}$
}

\author{
M. D. KERN \\ Biology Department, The College of Wooster,Wooster, OH 44691, e-mail: mkern@acs.wooster.edu \\ R. J. Cowie and F. M. Slater \\ School of Biosciences, Cardiff University, P.O. Box 915, Cardiff CF1 3TL, U.K.
}

\begin{abstract}
Previous studies with small numbers of clutches suggested that Pied Flycatchers (Ficedula hypoleuca) were determinate egg-layers whose clutch size was fixed before laying began. We found that females lay additional eggs of normal size if clutch size is experimentally reduced, but do not lay fewer eggs when clutch size is increased. In the terms of Kennedy and Power (1990), Pied Flycatchers are removal-indeterminate and addition-determinate.
\end{abstract}

Key words: determinate egg-laying, Ficedula hypoleuca, indeterminate egg-laying, Pied Flycatcher.

Birds are commonly grouped as determinate or indeterminate egg layers depending upon how they respond to alterations in clutch size while laying. Determinate layers do not respond to such changes, but lay a fixed number of eggs. Indeterminate layers, on the other hand, compensate for egg removal or addition by laying more or fewer eggs to keep clutch size approximately constant (Kennedy 1991).

Until recently, the Pied Flycatcher (Ficedula hypoleuca) was considered a determinate layer (Berndt 1943, von Haartman 1967). The evidence was slim, however, and led Haywood (1993) in a review of egglaying patterns to conclude that the status of this species was still uncertain. Several facets of their natural history suggest that Pied Flycatchers may in fact be indeterminate layers. For example, the number of yolky follicles that develop in the ovary exceeds clutch size (Silverin 1980) and levels of luteinizing hormone, which is required for ovulation, are moderate to elevated throughout the laying and incubating phases of the breeding cycle (Silverin and Wingfield 1982). This would presumably enable the birds to produce additional eggs if circumstances warranted it. Furthermore, the clutch size of Pied Flycatchers is highly variable ( $<4$ to 10 eggs) (Järvinen 1989), not rigidly fixed by the genotype (Lundberg and Alatalo 1992), and flexible. Several proximate factors can influence it, including the type of woods in which the birds nest (Gezelius et al. 1984), food availability (Sanz and Moreno 1995), female size and condition (Askenmo 1982), population density (Alatalo and Lundberg 1984), and even the size of the nest box (Karlsson and Nilsson 1977). In other words, the potential for producing additional eggs is clearly present in this passerine.

It might, however, be in the flycatchers' best inter-

\footnotetext{
${ }^{1}$ Received 28 April 1999. Accepted 29 November 1999.
}

ests to limit the eggs they lay to a number below the most productive clutch size (Moreno et al. 1991), if it would improve their fitness. With a smaller clutch, they could keep egg size large, an important factor in the growth and survival of the chicks (Järvinen and Väisänen 1983, Järvinen and Ylimaunu 1984), and perhaps simultaneously enhance their own survival and fecundity in the future given that large clutches carry high immediate and future costs of reproduction for flycatchers (Nur 1988, Gustafsson and Pärt 1990).

In any event, previous studies suggesting that Pied Flycatchers are determinate layers involved only 9 (von Haartman 1967) and 17 nests (Berndt 1943) and few-to-no replicate manipulations of clutch size, and are therefore difficult to interpret. This and the evolutionary importance of egg-laying patterns led us to re-examine the status of Pied Flycatchers, to include a recently developed method of evaluating the laying pattern (Kennedy 1991), and to determine whether Pied Flycatchers enlarge their clutches by producing eggs that are smaller than normal, as Least Flycatchers (Empidonax minimus) do (Briskie 1985).

\section{METHODS}

The female Pied Flycatchers in our study used nest boxes in several deciduous or mixed deciduous-conifer woods, dominated by sessile oaks (Quercus petraeca), within $10 \mathrm{~km}$ of Newbridge-on-Wye, Powys, Wales, U.K. $\left(52^{\circ} \mathrm{N}, 3^{\circ} \mathrm{W}\right)$.

During the 1993 nesting season, we removed the first and all subsequent eggs as they were laid from 11 nests, a method commonly used in previous studies to determine egg-laying patterns. These were the first clutches of the females: egg laying began between 10 and 22 May.

In 1994, we removed, added, or switched two eggs in 73 nests as specified by Kennedy's (1991) method for determining egg-laying patterns. Two eggs were removed from a nest on the day they were laid, beginning with egg 1 ( $n=12$ nests), egg 2 (10 nests), or egg 4 (10 nests). Two eggs were added, one per day, to complete nests that were still empty and in which females subsequently laid (9 nests), or to nests after egg 1 (10 nests) or egg 4 (9 nests) was laid. Eggs 1 and 2 were switched in 13 additional (control) nests. The empty nests to which eggs were added had nest cups that were well molded, generally a sign that laying is about to start. Egg laying began in these nests one to several days later and the eggs we provided became a part of the clutch in all cases.

We used a similar experimental protocol in 1998. Two eggs were removed from a nest as laid, beginning 
with egg 1 ( $n=10$ nests) or egg 4 (10 nests). Two eggs, one per day, were added to other nests after the female had laid egg 1 (10 nests) or egg 4 (10 nests). Eggs 1 and 2 or 4 and 5 were swapped in another 20 (control) nests.

All of the egg sets studied in 1994 and 1998 were first clutches. Because the clutch size of Pied Flycatchers decreases during the nesting season at a rate of 0.07 eggs day ${ }^{-1}$, at least in Finland where this well known "calendar effect" was first described by von Haartman (1967), we used only clutches in which egg laying began between 7 and 14 May. The mean dates of clutch initiation among our groups ranged from 10 to 13 May.

To be sure that the females in the 1994 and 1998 groups had finished laying, we continued to monitor their clutches during incubation, and in most cases until the chicks hatched. In 1994, 67 clutches hatched; the other 7 were either deserted $(n=4)$ or depredated $(n=3)$ during the incubation period. In 1998, 49 clutches are known to have hatched chicks and the other 11 to have been incubated for 2 or more days.

In all three seasons, we measured the dimensions of the eggs with digital calipers $( \pm 0.01 \mathrm{~mm})$ to determine their volumes $\left(\mathrm{V}_{\mathrm{egg}}\right)$ by means of the equation $\mathrm{V}_{\text {egg }}=0.50 \mathrm{LB}^{2}$ where $\mathrm{L}$ and $\mathrm{B}$ are the egg's length and maximum breadth, in cm (Kern and Cowie 1996).

\section{MEASURES OF FEMALE CONDITION AND TERRITORY QUALITY}

Age, previous breeding experience, physical condition, and territory quality are all factors that can influence the clutch size of female Pied Flycatchers (Lundberg and Alatalo 1992). We had enough ancillary information about the birds in our study populations to examine the possible influences of the females' condition and the quality of their territories on clutch size. We used egg size as an indirect measure of female condition because heavier birds, in better condition, lay larger eggs than lighter females (Järvinen and Väisänen 1984). We compared egg size in clutches of 6-7 and 8-9 eggs to determine whether differences in clutch size depended on the condition of the female.

We also examined the possibility that clutch size is related to territory quality at the two major study sites for which we have five or more consecutive years of data. Pied Flycatchers have type B territories, the value of which is reflected by how often each nest box has been used. Territory quality (Q) can be measured therefore using the equation $\mathrm{Q}=\mathrm{u}-\mathrm{a}^{-1}$ (Potti 1993) where $\mathrm{u}=$ the number of years that a nest box was used by Pied Flycatchers and $\mathrm{a}=$ the number of years that the nest box was available (i.e., not occupied by another species). The value of $\mathrm{Q}$ increases with the number of years in which the nest box has been available, but for any given period higher values indicate better quality.

\section{STATISTICAL ANALYSES}

We compared responses to addition or removal of eggs with the control situation (egg swaps) using MannWhitney $U$-tests, 1-tailed because we expected differences in only one direction. In analyzing the 1994 data, we combined results from nests in which eggs were added on days 0-2 of egg laying into an "early ad- ditions" group and results from nests in which eggs were removed on days 1-3 into an "early removal" group because of small sample sizes. In 1998, we combined data from nests in which eggs were swapped on days $1-2$ or $4-5$ into a single control group because the distribution of clutch sizes was similar in both cases $(U$-test, $P>0.2)$. We used single-factor analysis of variance to compare the mean $\mathrm{V}_{\text {egg }}$ of the groups in the 1994 and 1998 populations, and Student's $t$-tests and Spearman's rank correlation analysis to examine relationships between clutch or egg size and measures of the flycatchers' condition or the quality of their territories. The values reported are means $\pm \mathrm{SD}$.

\section{RESULTS}

\section{EXPERIMENT}

In the manipulated nests, one female laid a new egg on 18 consecutive days, but each of the other 10 flycatchers laid 5-8 eggs: 5 eggs (1 female), 6 eggs (1), 7 eggs (5), and 8 eggs (3). This distribution (not including the 18-egg clutch) is not significantly different from that of 17 unmanipulated nests that were initiated during the same 13-day interval in 1993 ( $U$-test, $P>$ 0.2 ). The clutch size of these 10 manipulated females averaged $7.00 \pm 0.94$ eggs, which was nearly identical to the clutch size of $6.71 \pm 0.77$ eggs in the 17 unmanipulated nests.

Egg volume was not related to the position of an egg in these 10 clutches: the largest egg within individual clutches varied, for example, from the first to the last egg laid. The mean volume was $1.61 \pm 0.08$ $\mathrm{cm}^{3}$ with $(n=88$ eggs $)$ or without ( $n=70$ eggs $)$ the 18-egg clutch. Within the latter, $\mathrm{V}_{\text {egg }}$ averaged $1.57 \pm$ $0.06 \mathrm{~cm}^{3}$ and showed distinct peaks in eggs 5,10 , and 15 .

\section{AND 1998 EXPERIMENTS}

Adding eggs to the nest had no effect on clutch size in either 1994 or 1998 (Table 1). Clutch size was, however, increased significantly when eggs were removed from the nest during early laying in 1998 (Table 1). With one exception, the only females that laid 9-egg clutches, rare in our area (Campbell 1955, pers. observ.), were those with eggs removed (Table 1). None of the other clutches in manipulated nests was outside the normal 4- to 8-egg range characteristic of our populations.

The average $\mathrm{V}_{\text {egg }}$ in the groups ranged from 1.53 to $1.61 \mathrm{~cm}^{3}$ in 1994 , and 1.54 to $1.62 \mathrm{~cm}^{3}$ in 1998 . Volume was not influenced by changes in clutch size during either year (ANOVA: $F_{4,62}=0.6$ in 1994, $F_{4,54}=$ 1.0 in 1998; $P>0.5$ in both cases).

Although females in the early removal group responded significantly to manipulations in clutch size (Table 1), the average $\mathrm{V}_{\text {egg }}$ of those which laid clutches of 6-7 eggs was not significantly different $(P>0.5)$ from that of females which laid clutches of 8-9 eggs in either 1994 ( 1.57 vs. $1.60 \mathrm{~cm}^{3}, 7$ vs. 12 females) or 1998 (1.74 vs. $1.72 \mathrm{~cm}^{3}, 4$ vs. 6 females).

Territory quality averaged $79.2 \%$ and $77.1 \%$ of maximum possible values in 1994 and 1998, respectively. Clutch size was not significantly related to it in any of the 1994 groups. In 1998, however, clutch size was weakly correlated with Q in the "early removal" 
TABLE 1. The effects of altering the number of eggs in the nests of Pied Flycatchers at various times during the egg-laying period. ${ }^{\mathrm{a}, \mathrm{b}}$

\begin{tabular}{|c|c|c|c|c|c|c|c|c|c|c|}
\hline \multirow[b]{2}{*}{ Year } & \multirow[b]{2}{*}{ Treatment } & \multirow{2}{*}{$\begin{array}{l}\text { Dates when } \\
\text { egg laying } \\
\text { began }\end{array}$} & \multirow{2}{*}{$\begin{array}{l}\text { Clutches } \\
(n)\end{array}$} & \multicolumn{5}{|c|}{ Clutches $(n)$ with sizes of } & \multirow[b]{2}{*}{ Clutch size } & \multirow[b]{2}{*}{$P$-value ${ }^{\mathrm{c}}$} \\
\hline & & & & 4 & 6 & 7 & 8 & 9 & & \\
\hline \multirow[t]{7}{*}{1994} & Swaps & 7-11 May & 13 & & 3 & 7 & 3 & & $7.00 \pm 0.71$ & - \\
\hline & Additions & & & & & & & & & \\
\hline & Days $0-2$ & 10-14 May & 19 & 1 & 7 & 9 & 2 & & $6.58 \pm 0.90$ & ns \\
\hline & Days $4-5$ & 11-14 May & 9 & & 1 & 7 & 1 & & $7.00 \pm 0.50$ & $\mathrm{~ns}$ \\
\hline & Removals & & & & & & & & & \\
\hline & Days $1-3$ & 8-14 Мау & 22 & & 5 & 4 & 10 & 3 & $7.50 \pm 1.01$ & 0.07 \\
\hline & Days $4-5$ & 7-14 Мау & 10 & & 2 & 5 & 3 & & $7.10 \pm 0.74$ & ns \\
\hline \multirow[t]{7}{*}{1998} & Swaps & 9-13 Мау & 20 & & 2 & 12 & 6 & & $7.20 \pm 0.62$ & - \\
\hline & Additions & & & & & & & & & \\
\hline & Days 1-2 & 12 May & 10 & & 2 & 8 & & & $6.80 \pm 0.42$ & ns \\
\hline & Days $4-5$ & 9-11 May & 10 & & 2 & 6 & 1 & 1 & $7.10 \pm 0.88$ & $\mathrm{~ns}$ \\
\hline & Removals & & & & & & & & & \\
\hline & Days $1-2$ & 12 May & 10 & & 1 & 3 & 5 & 1 & $7.60 \pm 0.84$ & $<0.02$ \\
\hline & Days $4-5$ & 9-11 May & 10 & & 1 & 5 & 2 & 2 & $7.50 \pm 0.97$ & 0.07 \\
\hline
\end{tabular}

a "Swaps" = exchanges of 2 eggs between a pair of nests. This constitutes the control group in each year.

b Day $0=$ addition of eggs to finished nests prior to laying. Day $1=$ first day of laying.

c Mann-Whitney $U$-tests.

group ( $r_{\mathrm{s}}=0.79, P=0.06, n=6$ nest boxes), and more strongly so in the "late additions" group $\left(r_{\mathrm{s}}=\right.$ $0.94, P=0.04, n=5$ nest boxes).

\section{DISCUSSION}

In the terms of Kennedy and Power (1990), Pied Flycatchers are addition-determinate, but removal-indeterminate egg layers. The addition-determinance may mean that females lay a minimal number of eggs under any circumstance, although that number can vary between individuals. The removal-indeterminance shown in Table 1 suggests that some females can apparently lay more than this minimal number. The results of the 1993 experiment are consistent with this interpretation assuming the one unusual clutch of 18 eggs was produced by a single female. Several factors suggest that only one bird laid this clutch in spite of its three peaks in $\mathrm{V}_{\text {egg. }}$. To begin with, there was no instance in which two eggs were laid in this nest box on the same day. In our experience, when a nest box is deserted by one female and taken over by another, the nest is usually refurbished and laying does not begin for several days. No such refurbishing occurred and there was no gap in laying - one egg was produced on each of 18 consecutive days.

Why some Pied Flycatchers lay more than the normal complement of eggs when clutch size is reduced early in the egg-laying period and others do not (Table 1 ) is unknown. Age, however, may play a role given that first-year birds often produce smaller clutches than older adults (von Haartman 1967, Järvinen 1991) and the optimal clutch size increases with age in the closely related Collared Flycatcher (Ficedula albicollis; Gustafsson 1990).

The bird's size and condition may also be important because large and heavy females produce larger eggs and clutches than small birds (Järvinen and Väisänen 1983, Potti 1993). Our study, however, provides no support for this possibility as there was no difference in $\mathrm{V}_{\text {egg }}$ between females in the "early removal" group that laid clutches of 6-7 eggs and those that laid clutches of 8-9 eggs in either 1994 or 1998.

Territory quality could also be a factor, particularly because it is the most important criterion that female Pied Flycatchers use when selecting a mate (Alatalo et al. 1986). Högstedt (1980) has suggested for magpies that all females produce clutches of the most productive size, but that clutch size varies among individuals because they occupy territories of different quality. Recent work in which the nests of Pied Flycatchers were moved from deciduous to coniferous sites prior to egg laying without females deserting (Siikamäki 1995) supports this hypothesis. In general, the birds in our populations nested at high-quality sites in both 1994 and 1998. Furthermore, clutch size in 1998 was related to $\mathrm{Q}$ in two groups, one of which was the "early removal" group, i.e., the group which responded to egg removal by laying additional eggs (Table 1). Our data are then consistent with the premise that birds occupying superior territories are able to lay more than the minimal number of eggs. The quality of the nest box itself was probably not a factor in our study because all but two of our boxes are uniform in size and construction.

Breeding experience could also be a factor. Harvey et al. (1985) found that at least $40 \%$ of 2-year-old female Pied Flycatchers nesting in the Forest of Dean, Great Britain, had no breeding experience at all. More recently, Nur (1988) concluded that female flycatchers acquire the ability to adapt clutch size to prevailing environmental conditions gradually and that only prior experience in the nesting area enables them to adjust clutch size appropriately. It is therefore possible that experienced birds respond to egg removal, whereas first-time breeders do not.

The reason why indeterminate laying has not been observed in Pied Flycatchers previously may reflect differences in methods of assessing laying patterns. It 
may be difficult to detect indeterminate responses in species like Pied Flycatchers that have highly variable clutch sizes unless large numbers of nests are manipulated. We believe this is why our findings differ from those of Berndt (1943) and von Haartman (1967) whose sample sizes were very small.

Haywood (1993) has proposed that egg-laying patterns are evolutionary responses to the amount of food available to female birds when the eggs are forming. That is, indeterminate responses will occur when the food supply in the nesting area varies in an unpredictable manner from year to year, whereas determinate responses will evolve when the food supply remains reasonably constant. As far as Pied Flycatchers are concerned, there is considerable support for this hypothesis because such proximate factors as habitat characteristics, the abundance of food when the birds are laying, female condition, and weather affect their clutch size (Lundberg and Alatalo 1992).

Kennedy and Power (1990), on the other hand, have proposed that nest parasitism and predation are ultimately responsible for indeterminate laying patterns and that they may act independently. As a result, a species may respond to either the addition or removal of eggs, both, or neither. As far as Pied Flycatchers are concerned, there is less support for this hypothesis. We have, for example, cases in which two females laid eggs in the same nest and in which nests suffered losses of one to several eggs to predators (mice and possibly jays or crows), and conspecific egg parasitism has been documented previously in Pied Flycatchers (Högstedt, cited in MacWhirter 1989). Unless parasitism is so infrequent that it does not affect fitness in clutches of large size (Power et al. 1989), we might therefore expect these flycatchers to be both additionand removal-indeterminate, rather than addition-determinate and removal-indeterminate (Table 1).

Pied Flycatchers are certainly indeterminate layers in the sense that more yolky follicles develop in the ovary than are laid (Silverin 1980). The extra ones can be used to replace the first clutch if it is destroyed, but they might also be a source of additional eggs for the initial clutch. The moderate-to-high levels of luteinizing hormone that persist throughout the laying and incubating phases of the breeding cycle (Silverin and Wingfield 1982) would presumably enable flycatchers to produce these additional eggs if an occasion warranted it. Some do, but others apparently do not (Table 1). Nonetheless, even when females do respond to the removal of eggs from their nests, the clutch generally stays within the normal range for the species (Table 1) and egg size remains large.

We thank P. Tantrum and K. A. Hughson on whose properties we did our experiments. We are grateful to the Llysdinam Trust for making the facilities of its Field Centre available to us. This paper has benefited substantially from the suggestions and thoughtful comments of several reviewers, including T. R. Anderson, E. D. Kennedy, H. Power, and S. G. Sealy. Our experiments were conducted under licenses SB:7:93, SB: 4:94, and SB:5:98 issued to RJC by the Countryside Council for Wales. MDK was supported by grants from the Howard Hughes and the Luce Foundations and by faculty development funds from the College of Wooster.

\section{LITERATURE CITED}

Alatalo, R. V., And A. Lundberg. 1984. Density-dependence in breeding success of the Pied Flycatcher (Ficedula hypoleuca). J. Anim. Ecol. 53: 969-977.

Alatalo, R. V., A. Lundberg, and C. Glynn. 1986. Female Pied Flycatchers choose territory quality and not male characteristics. Nature 323:152-153.

Askenmo, C. 1982. Clutch size flexibility in the Pied Flycatcher Ficedula hypoleuca. Ardea 70:189196.

BERNDT, R. 1943. Wie reagiert der Trauerfliegenschnäpper, Muscicapa h. hypoleuca (Pall.), auf die Fortnahme seines Geleges während der Legeperiode? Beit. Fortpflanzungsbiol. Vogel Berücksicht. Oologie 19:77-78.

BRISKIE, J. V. 1985. Growth and parental feeding of Least Flycatchers in relation to brood size, hatching order and prey availability. M.Sc. thesis, Univ. Manitoba, Winnipeg, Manitoba, Canada.

CAMPBEll, B. 1955. A population of Pied Flycatchers (Muscicapa hypoleuca). Proc. Int. Ornithol. Congr. 11:428-434.

Gezelius, L., L. M. Grahn, H. KÄllander, and J. KARLSSON. 1984. Habitat-related differences in clutch size of the Pied Flycatcher Ficedula hypoleuca. Ann. Zool. Fenn. 21:209-212.

GuSTAFSSON, L. 1990. Life-history trade-offs and optimal clutch size in relation to age in the Collared Flycatcher, p. 235-245. In J. Blondel, A. Gosler, J.-D. Lebreton, and R. McCleery [EDS.], Population biology of passerine birds. An integrated approach. Springer-Verlag, London.

Gustafsson, L., AND T. PÄRT. 1990. Acceleration of senescence in the Collared Flycatcher Ficedula albicollis by reproductive costs. Nature 347:279281.

Harvey, P. H., M. J. Stenning, and B. Campbell. 1985. Individual variation in seasonal breeding success of Pied Flycatchers (Ficedula hypoleuca). J. Anim. Ecol. 54:391-398.

HAYwOOD, S. 1993. Sensory and hormonal control of clutch size in birds. Quart. Rev. Biol. 68:33-60.

HögstedT, G. 1980. Evolution of clutch size in birds: adaptive variation in relation to territory quality. Science 210:1148-1150.

JÄRVINEN, A. 1989. Clutch-size variation in the Pied Flycatcher Ficedula hypoleuca. Ibis 131:572-577.

JäRVINEN, A. 1991. A meta-analytic study of the effects of female age on laying-date and clutch-size in the Great Tit Parus major and the Pied Flycatcher Ficedula hypoleuca. Ibis 133:62-67.

JÄRVINEN, A., AND R. A. VÄISÄNEN. 1983. Egg size and related reproductive traits in a southern passerine Ficedula hypoleuca breeding in an extreme northern environment. Ornis Scand. 14:253-262.

JÄRVINEN, A., AND R. A. VÄISÄNEN. 1984. Reproduction of Pied Flycatchers (Ficedula hypoleuca) in good and bad breeding seasons in a northern marginal area. Auk 101:439-450.

JÄRVINEN, A., AND J. YlimAUnU. 1984. Significance of 
egg size on the growth of nestling Pied Flycatchers Ficedula hypoleuca. Ann. Zool. Fenn. 21:213216.

Karlsson J., and S. G. Nilsson. 1977. The influence of nest-box area on clutch size in some hole-nesting passerines. Ibis 119:207-211.

KenneDy, E. D. 1991. Determinate and indeterminate egg-laying patterns: a review. Condor 93:106124.

Kennedy, E. D., ANd H. W. Power. 1990. Experiments on indeterminate laying in House Wrens and European Starlings. Condor 92:861-865.

Kern, M. D., AND R. J. CowIE. 1996. The size and shape of eggs from a Welsh population of Pied Flycatchers-testing Hoyt's use of egg dimensions to ascertain egg volume. J. Field Ornithol. 67:72-81.

LundberG, A., And R. V. Alatalo. 1992. The Pied Flycatcher. T. and A. D. Poyser, London.

MACWhirTER, R. B. 1989. On the rarity of intraspecific brood parasitism. Condor 91:485-492.

Moreno, J., L. Gustafsson, A. Carlson, and T. Pärt. 1991. The cost of incubation in relation to clutchsize in the Collared Flycatcher Ficedula albicollis. Ibis 133:186-193.

Nur, N. 1988. The cost of reproduction in birds: an examination of the evidence. Ardea 76:155-168.
Power, H. W., E. D. Kennedy, L. C. Romagnano, M. P. Lombardo, A. S. Hoffenberg, P. C. Stouffer, AND T. R. MCGuIRE. 1989. The parasitism insurance hypothesis: why starlings leave space for parasitic eggs. Condor 91:753-765.

PotTi, J. 1993. Environmental, ontogenetic, and genetic variation in egg size of Pied Flycatchers. Can. J. Zool. 71:1534-1542.

SANZ, J. J., AND J. MoRENO. 1995. Experimentally induced clutch size enlargements affect reproductive success in the Pied Flycatcher. Oecologia 103: 358-364.

SIIKAMÄKI, P. 1995. Habitat quality and reproductive traits in the Pied Flycatcher-an experiment. Ecology 76:308-312.

SILVERIN, B. 1980. Seasonal development of reproductive organs in the female Pied Flycatcher Ficedula hypoleuca and experimental studies on duration of her re-nesting ability. J. Zool. 190:241-257.

Silverin, B., AND J. C. Wingfield. 1982. Patterns of breeding behaviour and plasma levels of hormones in a free-living population of Pied Flycatchers, Ficedula hypoleuca. J. Zool. 198:117129.

Von Haartman, L. 1967. Clutch-size in the Pied Flycatcher. Proc. Int. Ornithol. Congr. 14:155-164.

\title{
EGG RECOGNITION IN YELLOW-BILLED AND BLACK-BILLED MAGPIES IN THE ABSENCE OF INTERSPECIFIC PARASITISM: IMPLICATIONS FOR PARASITE-HOST COEVOLUTION ${ }^{1}$
}

\author{
GINGER M. BOLEN ${ }^{2}$ \\ Museum of Vertebrate Zoology, 3101 VLSB, University of California, Berkeley, CA 94720 \\ STEPHEN I. ROTHSTEIN \\ Department of Ecology, Evolution and Marine Biology, University of California, Santa Barbara, CA 93106 \\ Charles H. Trost \\ Department of Biology, Idaho State University, Box 8007, Pocatello, ID 83209
}

\begin{abstract}
Yellow-billed Magpies (Pica nuttalli) ejected $100 \%$ of nonmimetic eggs placed in their nests despite such behavior having no detectable present day benefits. They are not currently parasitized, nor is there any evidence of a recently extinct brood parasite. Furthermore, there was no molecular evidence of conspecific parasitism, and Yellow-billed Magpies accepted

\footnotetext{
${ }^{1}$ Received 30 August 1999. Accepted 21 January 2000.

${ }^{2}$ Current address: Conservation and Research Center, 1500 Remount Road, Front Royal, VA 22630, e-mail: gingerbolen@excite.com
}

eight of nine conspecific eggs transferred between nests, so recognition would rarely be of benefit if conspecific parasitism occurred. Thus, we suggest that egg recognition in Yellow-billed Magpies is a plesiomorphic trait, a primitive character inherited from a remote ancestor, its nearest relative, the Black-billed Magpie (Pica pica). The latter suffers from parasitism by Great Spotted Cuckoos (Clamator glandarius) in Eurasia and displays rejection behavior throughout Europe in populations that are allopatric and sympatric with this cuckoo. As would be expected if Yellowbilled Magpies inherited rejection behavior from the Black-billed Magpie, or the common ancestor of both species, we found that North American Black-billed 
Magpies also have well developed egg recognition despite being unaffected by interspecific parasitism. The long-term retention of host defenses as is indicated by magpies has major implications for the coevolutionary interactions between brood parasites and their hosts.

Key words: Black-billed Magpie, brood parasitism, coevolution, egg recognition, Pica nuttalli, Pica pica, Yellow-billed Magpie.

A generalization arising from previous studies of egg recognition is that it is well developed in many species that are actual or potentially suitable hosts of current brood parasites (Rothstein 1975, 1990, Moksnes et al. 1991). Such suitable host species are currently parasitized or could be parasitized given basic aspects of their breeding biology, such as the food they feed their nestlings and nests that are accessible to known obligate parasites. Although many actual and potential hosts lack egg recognition (Rothstein 1975a), most likely due to evolutionary lag (Rothstein 1990) or costs incurred by host defenses (Rohwer and Spaw 1988, Lotem et al. 1995), recognition behavior is much more prevalent among these species than among species that are unsuitable as hosts. This difference between the behavior of suitable and unsuitable hosts is strong evidence that obligate brood parasites are the primary selective pressure responsible for the evolution of egg recognition (Davies and Brooke 1989a, Rothstein 1990, Moksnes et al. 1991).

A particularly interesting category of suitable hosts are populations that are no longer parasitized, either because they have become allopatric with respect to parasites that could victimize them or because parasites have shifted to other hosts (Soler et al. 1998). Retention of egg recognition in the absence of selection has significant implications for the long-term coevolution between parasitic birds and their hosts (Rothstein 1990).

Here we present evidence for the retention of egg recognition in the absence of brood parasitism in Yellow-billed Magpies (Pica nuttalli). We studied this species for two reasons. First, the Yellow-billed Magpie is well beyond the size range of birds that can be parasitized successfully (Friedmann and Kiff 1985) by its only sympatric brood parasite, the Brown-headed Cowbird (Molothrus ater). Furthermore, the latter has been sympatric with the Yellow-billed Magpie for less than a century (Rothstein 1994) and no other obligate brood parasite is known to have been sympatric with the species during the period of historical records.

Second, its only congener, the Black-billed Magpie ( $P$. pica), shows highly developed egg discrimination in parts of Europe where it is heavily parasitized by the Great Spotted Cuckoo (Clamator glandarius). The Black-billed Magpie also is a host of the Koel (Eudynamys scolopacea), a cuckoo with which it is sympatric in Asia (Johnsgard 1997). Both cuckoos lay eggs similar to those of the magpie. Soler and Møller (1990) reported that parasitized populations of Black-billed Magpies in Spain show varying levels of discrimination of mimetic cuckoo eggs that relate to the duration of each population's sympatry with Great Spotted Cuckoos. Extensive experiments on six other European Black-billed Magpie populations allopatric with this cuckoo show that each exhibits rejection rates of $52.9 \%$ to $100 \%$ for nonmimetic eggs (Soler et al. 1999). Thus, direct contact with cuckoos is not necessary to maintain high levels of egg recognition in Black-billed Magpies.

Given the Yellow-billed Magpie's lack of recent contact with brood parasites and the widespread presence of egg recognition in European Black-billed Magpies, we assumed that a demonstration of egg recognition in Yellow-billed Magpies would indicate that this behavior may be retained for extremely long periods of time (thousands of generations), possibly even through a speciation event. This hypothesis depends on three assumptions concerning the Yellow-billed Magpie: (1) neither inter- nor intra-specific parasitism is currently maintaining egg recognition, (2) neither inter- nor intra-specific parasitism has occurred during the recent history of the species, and (3) the species is descended from an allopatric population that diverged from the Black-billed Magpie.

In addition to reporting on Yellow-billed Magpie responses to nonmimetic eggs, we report on their response to conspecific eggs as a partial test of the possible importance of intraspecific parasitism. Finally, we report the responses of North American Black-billed Magpies (P. p. hudsonia) to nonmimetic eggs as a partial test of the hypothesis that Yellow-billed Magpies retained egg-recognition from a Black-billed Magpie ancestor.

\section{METHODS}

Experiments on Yellow-billed Magpies were conducted at Hastings Natural History Reservation and the adjacent Oak Ridge Ranch in Carmel Valley, California. Most of this area is steep hillside with scattered, open oak savanna.

Experiments with nonmimetic eggs were initiated by placing a single nonmimetic egg in each of 12 nests. Nonmimetic eggs were either model eggs cast in plaster of Paris and painted red, blue, or white, or real quail (Coturnix sp.) eggs given a red coat of paint that allowed the egg markings to show through. Previous studies have shown that rejecter species respond to plaster eggs in the same ways as to real eggs (Rothstein 1975a, 1975b), whereas accepter species, including other species of corvids, do not reject highly nonmimetic eggs (Yom-Tov 1976, Soler 1990).

Our use of quail eggs matches the procedure Soler and Møller (1990) used to test for egg recognition and rejection in Black-billed Magpies in Europe. Plaster and quail eggs were painted to make them easily distinguishable from magpie eggs because our initial goal was not to test the limits of magpie discrimination but to determine whether they show any discrimination at all. Similarly, introduced eggs were also distinct from magpie eggs in size. Yellow-billed Magpie eggs average $31.5 \times 22.5 \mathrm{~mm}$ (Reynolds 1995) compared to $28.3 \times 20.7 \mathrm{~mm}$ for the plaster and $32.6 \times 25.7 \mathrm{~mm}$ for the quail eggs. We then checked each nest five to six days after addition of the nonmimetic egg to determine whether egg rejection (removal from nest) occurred. Less than $1 \%$ of the rejections in related studies occurred after day five, so eggs accepted for five days 
TABLE 1. Percent of eggs rejected by Yellow-billed Magpies within five days of addition to clutch.

\begin{tabular}{llcccc}
\hline \hline Type of egg added & Nesting stage & Host egg removed & Host egg not removed & \multicolumn{2}{c}{ Total } \\
\hline Nonmimetic & incubation & $100(3 / 3)$ & $100(5 / 5)$ & $100(8 / 8)$ \\
Mimetic & laying & $100(2 / 2)$ & $\sim^{\mathrm{a}}$ & $100(2 / 2)$ \\
& incubation & $0.0(0 / 5)$ & $33.3(1 / 3)^{\mathrm{b}}$ & $0.1(1 / 8)$ \\
& laying & $-^{\mathrm{a}}$ & $0.0(0 / 1)$ & $0.0(0 / 1)$ \\
\hline
\end{tabular}

a Manipulation not done.

${ }^{b}$ One nest at which there was no rejection had previously been used in a model egg manipulation.

were equated with eggs that had been accepted for the full life of the nest (Rothstein 1975a).

Nonmimetic-egg experiments in 1996 and 1997 indicated that Yellow-billed Magpies show egg discrimination. Thus, we also performed mimetic egg experiments by switching eggs between magpie nests in 1997 to test the degree of discrimination. Experiments with mimetic eggs were initiated by using a permanent marker to place a small number on each magpie egg corresponding to the nest in which it originated. We then placed a single mimetic egg (a magpie egg from a different nest) into nine experimental nests. Nests were checked five days later to determine the response to the manipulation.

All manipulations were done between 06:00 and 18:00. The majority of trials began after egg laying at the nest was finished (incubation phase), however, a few trials began during the laying phase. During each nest check, all eggs were removed from the nest and checked for peck marks or other damage. To control for the possibility that eggs might be rejected due to an increased number of eggs in the nest, one host egg was removed from the host clutch in 5 of 10 nonmimetic trials and 5 of 9 mimetic trials. Unless otherwise stated, no nest was used for more than one trial.

Egg-recognition experiments on Yellow-billed Magpies suggested that the ability to recognize foreign eggs may have been retained from a Black-billed Magpie ancestor. Thus, in 1999, nonmimetic-egg recognition experiments were conducted on North American Black-billed Magpies on the Sterling Wildlife Management Area in southeastern Idaho. We placed a single nonmimetic egg in each of 13 nests. Nonmimetic eggs were made by painting one egg red or white in each nest. Twelve egg replacements occurred during the incubation phase and one during the laying phase. We then checked each nest 24-48 hr after addition of the nonmimetic egg to determine whether egg rejection occurred.

\section{RESULTS}

Timing of manipulation (laying vs. incubation), type of nonmimetic egg (plaster vs. quail), and removal vs. nonremoval of a host egg did not significantly affect Yellow-billed Magpie host response (two-tailed Fisher exact test, $P>0.05$ for all cases; Table 1), thus results were combined for analysis. In two nonmimetic trials, eggs hatched before the 5-day check for rejection, therefore these nests were not used in the analyses. Ejection of the nonmimetic egg occurred by day 5 at each of the 10 remaining nests. In one nest, one host egg as well as the nonmimetic egg was found to be missing, and an additional host egg showed damage. Rejection occurred in only one of nine mimetic egg trials $(11.1 \%)$, which is a significantly lower rejection rate than for nonmimetic eggs (two-tailed Fisher exact test, $P<0.001)$. The difference in rejection rate between nonmimetic and mimetic eggs was not due to easier detectability of model eggs as real and plaster nonmimetic eggs were rejected at equal frequencies $(2 / 2$ and $8 / 8$, respectively). Note, too, that most birds reject damaged eggs even if they display no egg recognition (Kemal and Rothstein 1988) and that the one mimeticegg rejection may have occurred due to damage we caused while transferring the egg from one nest to another, rather than to egg recognition. Unfortunately, the 14.2-m mean height of magpie nests in our study made nest access and handling of eggs difficult. Thus, the rejected mimetic egg was possibly, unknowingly, damaged.

In Black-billed Magpie nonmimetic-egg trials, rejection occurred at $100 \%$ of nests $(n=12)$. No damage was detected to any other eggs in the nests in which rejection occurred.

\section{DISCUSSION}

Yellow-billed Magpies do not now have, nor are they known to have ever had, interspecific nest parasites. However, in this study they rejected $100 \%$ of nonmimetic eggs placed into their nests. Because nonmimetic eggs were ejected at a $100 \%$ rate regardless of whether they replaced a magpie egg or were simply added to a clutch without removing a magpie egg, the birds clearly discriminated among egg types. We propose that this egg-recognition behavior is best explained as the retention of a trait that provided a selective advantage in the past, possibly inherited from an ancestor, the Black-billed Magpie, which does suffer from brood parasitism in the Old World.

Evidence does not support the alternative hypothesis that intraspecific brood parasitism has resulted in the evolution and/or maintenance of egg recognition in Yellow-billed Magpies. If intraspecific brood parasitism has selected for egg recognition, then birds should regularly reject conspecific eggs placed in their nests. Alternatively, if they do not show such rejection, then the hypothesis that intraspecific parasitism selected for recognition is invalidated. In this study, Yellow-billed Magpies rejected mimetic eggs at a low rate $(11.1 \%)$, suggesting that they do not have sufficient discrimination ability to reliably recognize foreign conspecific eggs. In addition, multilocus DNA fingerprinting of 10 broods (39 nestlings) revealed no evidence of intra- 
specific brood parasitism in the study population (Bolen 1999).

Interspecific brood parasitism also is unlikely to have occurred in the recent past. Yellow-billed (Coccyzus americanus) and Black-billed Cuckoos (C. erythropthalamus), both New World species, or their ancestors may have been obligate brood parasites (Hughes 1997). However, the Black-billed Cuckoo range does not currently overlap with the Yellow-billed Magpie range and only a small degree of geographic overlap exists between Yellow-billed Magpies and Yellow-billed Cuckoos. Moreover, Yellow-billed Cuckoo eggs are not mimetic to Yellow-billed Magpie eggs (immaculate light blue vs. heavily spotted, respectively) suggesting that they never specialized on Yellowbilled Magpies. In addition, no other obligate brood parasite is known to have been sympatric with the species during the period of historical records.

It might be suggested that magpies eject oddly colored eggs because they have sufficient cognitive ability to allow them to realize that such objects do not belong in their nests. Although corvids such as magpies show remarkable cognitive abilities (Savage 1995, Heinrich 1999), we reject this hypothesis because several species of Corvus as well as Pyrrhocorax accept strongly nonmimetic eggs (Yom-Tov 1976, Soler 1990). Even the Common Raven, Corvus corax, the corvid with the strongest cognitive skills yet demonstrated, accepts nonmimetic eggs (Soler 1990).

The third assumption, that the Yellow-billed Magpie is descended from the Black-billed Magpie, is supported by the extensive almost circumpolar range of the latter species and the small range of the Yellowbilled Magpie, which is limited to the Central Valley and adjacent areas of coastal California. If our hypothesis that the Yellow-billed Magpie inherited egg recognition from the Black-billed Magpie is correct, then North American Black-billed Magpies also should show rejection behavior despite an absence of interspecific parasitism. Furthermore, such rejection behavior would be evidence for retention of egg recognition in the absence of selection and gene flow as mitochondrial DNA data show a high degree of differentiation (3.9\% divergence) between Black-billed Magpies in northeast Asia and North America (Zink et al. 1995). This level of divergence suggests that the two populations have been separated for at least two million years (Moore and DeFilippis 1997).

Evidence from this study shows that at least one population of North American Black-billed Magpies do exhibit rejection behavior, $100 \%$ of nonmimetic eggs were rejected from experimental nests. The possibility, however, that such rejection behavior in this species is currently under selection pressure due to intraspecific brood parasitism cannot be ruled out (X. Wang, pers. comm.).

Because we are unable to identify any current or past selection pressure favoring egg recognition in Yellow-billed Magpies, and recognition cannot be due to introgression from Black-billed Magpies because the two species are allopatric, the Yellow-billed Magpie's recognition is best interpreted as a plesiomorphic trait inherited from an ancestral taxon. We cannot rule out the possibility that egg recognition in Yellow-billed
Magpies has some current adaptive value in a context unknown to us, but retention from an ancestral taxon is the most parsimonious explanation.

Here we have presented evidence that Yellow-billed Magpies have retained egg recognition in the absence of brood parasites for thousands of years, possibly even through a speciation event. The long-term retention indicated by our study implies that egg recognition of strongly nonmimetic eggs inflicts few or no costs, which is consistent with data on catbirds and most other North American rejecter species (Rothstein 1976). Thus, the Yellow-billed and Black-billed Magpie differ from most North American passerines, which show no indication of egg recognition even when given eggs strongly divergent from their own (Rothstein 1982a).

Unlike the magpies we tested, European Blackbilled Magpies are either sympatric with Great-spotted Cuckoos, which specialize on parasitizing them, or allopatric with this cuckoo but receiving gene flow from populations that are sympatric (Soler and Møller 1990, Soler et al. 1999). Because of selection or gene flow, these European populations should have higher rejection rates of nonmimetic eggs than the North American magpies we tested. Instead, the latter had higher rejection rates, and this is true even for European magpies experiencing cuckoo parasitism (Soler et al. 1999). Contrasting the nonmimetic egg rejection rates of European magpie populations $($ mean $=70.6 \%$, median $=$ $69.2 \%$, Soler et al. 1999) with the two North American populations we tested (mean and median $=100 \%$ ) results in a nearly significant result $(P=0.062$, twotailed Mann-Whitney $U$-test). It is unclear why our results failed to show the expected lower rates of rejection in North American magpies, much less higher rejection rates. Eight of 10 of our Yellow-billed Magpies were tested with plaster eggs, which were slightly smaller than magpie eggs, whereas Soler et al. (1999) used painted quail eggs, which are slightly larger than magpie eggs. But Soler et al. (1998) reported no difference between magpie responses to plaster and quail eggs. In addition, Black-billed Magpies in our study were given painted conspecific eggs, so for them introduced eggs differed little or not at all from their own eggs. Magpies in most regions have domed nests (Birkhead 1991), which may reduce light levels inside nests. For ease of access, we opened holes into nests so greater visibility of eggs may have been a factor in our study. Soler et al. $(1998,1999)$ did not address the issue of visibility in nests at which they conducted experiments. In addition, avian vision differs from human vision in a number of ways, including the ability of birds to detect ultraviolet light (Parrish et al. 1984). Thus, although both we and Soler et al. (1999) painted eggs red, there may have been spectral differences in the red paints used in the two studies. Regardless of whether the higher rejection rates in our study represent a real difference between European and North American magpies, or a difference in methodology, the salient result of our study is that the latter magpies have high rates of rejection, contrary to the hypothesis that egg recognition is lost in the absence of interspecific parasitism. Soler et al. (1999) showed that European magpies allopatric and sympatric with the Great 
Spotted Cuckoo differ more in rejection rate of mimetic eggs than of nonmimetic eggs. This result is expected because the fine discrimination needed to reject mimetic eggs is more likely to result in occasional mistaken rejections of a magpie's own eggs, so selection should decrease the tendency to reject mimetic eggs if a host population is no longer parasitized. Given this consideration, North American magpies should show less discrimination of mimetic eggs than do European magpies parasitized with cuckoos. Unfortunately, we cannot test this prediction adequately with our data. Compared to mimetic egg ejection rates of 11.1$63.6 \%$ for European magpies sympatric with the Great Spotted Cuckoo $($ mean $=38.7 \%$, median $=38.1 \%)$, only one of nine $(11.1 \%)$ Yellow-billed Magpies rejected a conspecific egg, which can be viewed as a mimetic foreign egg. But the mimetic eggs used by Soler et al. (1999) differed more from the host magpie eggs than the ones we used because they were smaller and were painted as opposed to having natural colors. Thus it is unclear whether Yellow-billed Magpies and European magpies differ in rejection rates of mimetic eggs.

Various cases of putative loss and retention of recognition (Rothstein 1977, Cruz and Wiley 1989, Davies and Brooke 1990) indicate that this behavior is retained as least as often as it is lost. The level of costs associated with an adaptation is likely to be a major factor determining the rate at which the adaptation is lost in the absence of selection. As described above, the discrimination needed to detect mimetic parasitic eggs is more likely to result in mistaken rejections of a host's own egg than is the discrimination needed to reject nonmimetic eggs. Because most cuckoo hosts are parasitized with mimetic eggs, unlike cowbird hosts (Rothstein 1990), cuckoo hosts should be more likely to show differences between populations sympatric and allopatric with parasites or even differences in recognition that are related to the level of cuckoo parasitism (Brooke et al. 1998). In accord with this expectation, studies of actual or potential cuckoo hosts (Cruz and Wiley 1989, Brown et al. 1990, Davies and Brooke 1990) are more likely to show variation in egg recognition behavior that correlates with the risk of parasitism than is the case for cowbird hosts (Cruz et al. 1985, Peer and Bollinger 1997) which in general show little or no geographic variation in response to foreign eggs (Rothstein 1975a, 1977, Peer and Bollinger 1997). However, there are exceptions to this trend. Great Reed Warblers (Acrocephalus arundinaceus) are parasitized by Common Cuckoos (Cuculus canorus) in parts of Japan, but a warbler population not in contact with cuckoos at Lake Biwa rejected eggs at as high a rate as a parasitized population $270 \mathrm{~km}$ away in Nagano (Nakamura et al. 1998). Briskie et al. (1992) reported that American Robins (Turdus migratorius) allopatric with cowbirds had a significantly lower rejection rate of cowbird eggs than a population sympatric with cowbirds. Thus, a number of other factors besides costs of rejection may be important in determining whether egg recognition is lost in the absence of parasitism. Despite evidence that egg recognition is sometimes lost in the absence of parasitism, it is clear from results presented here and elsewhere that it is often retained. Such retention of egg recognition has profound implications for the coevolutionary interactions between obligate brood parasites and their hosts. If hosts rapidly lose recognition in the absence of parasitism, parasites could go through cycles in which they shift from hosts with good defenses to ones with poor defenses, only to eventually shift back to their old hosts once these have lost their defenses (Davies and Brooke 1989b, Soler et al. 1998). Similarly, parasites will be able to utilize successfully all or most potential hosts when they colonize new regions that lack parasites, if recognition is rapidly lost in the absence of selection.

Alternatively, if recognition is retained for long periods in the absence of selection, cycles may be absent or may be so prolonged that their durations exceed the life spans of the species involved. Thus, long term retention could result in more and more potential host species acquiring and retaining egg recognition with parasites eventually becoming constrained to using a narrow subset of host species whose eggs can be mimicked with near perfection or whose biological features make acceptance of parasitic eggs a more adaptive option than rejection. Acceptance could be more adaptive than rejection for all members of a host species if the cost of parasitism is low or for a portion of a species, such as first time breeders that have not yet learned the range of variation of their own eggs (Lotem et al. 1995). Because evidence exists for both the retention and loss of recognition in the absence of parasitism, we suggest that this in part explains some of the considerable diversity that exists in the coevolutionary interactions between parasitic birds and their hosts.

This manuscript was greatly improved by comments from Todd Arnold, George Barlow, Harry Greene, Walt Koenig, Dale McCullough, Glen McMaster, and five anonymous reviewers. Thanks to Helen Osmond and Katie Kurkjian for assisting in the collection of the Yellow-billed Magpie data.

\section{LITERATURE CITED}

Bent, A. C. 1940. Life histories of North American cuckoos, goatsucker, hummingbirds, and their allies. U.S. Natl. Mus. Bull. No. 176.

Bolen, G. M. 1999. Extra-pair behavior in Yellowbilled Magpies (Pica nuttalli). Ph.D. diss., Univ. California, Berkeley, CA.

BirkhEAD, T. R. 1991. The magpies. Academic Press, San Diego, CA.

Briskie, J. V., S. G. Sealy, and K. A. Hobson. 1992. Behavioral defenses against avian brood parasitism in sympatric and allopatric host populations. Evolution 46:334-340.

Brooke, M de L., N. B. Davies, and D. G. Noble. 1998. Rapid decline of host defenses in response to reduced cuckoo parasitism: behavioural flexibility of reed warblers in a changing world. Proc. R. Soc. Lond. B 265:1277-1282.

Brown, R. J., M. N. Brown, M. DE L. Brooke, AND N. B. DAVIES. 1990. Reactions of parasitized and unparasitized populations of Acrocephalus warblers to model cuckoo eggs. Ibis 132:109-111.

Cruz, A., AND J. W. Wiley. 1989. The decline of an 
adaptation in the absence of a presumed selection pressure. Evolution 43:55-62.

Cruz, A., T. D. Manolis, And J. W. Wiley. 1985. The Shiny Cowbird: a brood parasite expanding its range in the Caribbean region. Ornithol. Monogr. 36.

Davies, N. B., AND M. DE L. Brooke. 1989a. An experimental study of co-evolution between the cuckoo, Cuculus canorus, and its hosts. I. Host egg discrimination. J. Anim. Ecol. 58:207-222.

Davies, N. B., AND M. DE L. BRoOKE. 1989b. An experimental study of co-evolution between the cuckoo, Cuculus canorus, and its hosts. II. Host egg markings, chick discrimination and general discussion. J. Anim. Ecol. 58:225-236.

Davies, N. B., AND M. DE L. BRooKe. 1990. Coevolution of the cuckoo and its hosts. Sci. Am. 264: 92-98.

FriedmanN, H., AND L. F. KIFF. 1985. The parasitic cowbirds and their hosts. Proc. West. Found. Vert. Zool. 2:225-304.

Harrison, H. H. 1979. A field guide to western birds nests. Houghton Mifflin, Boston.

HeinRICH, B. 1999. Mind of the raven: investigations and adventures with wolf-birds. Cliff Street Books, New York.

Hughes, J. M. 1997. Taxonomic significance of hostegg mimicry by facultative brood parasites of the avian genus Coccyzus (Cucilidae). Can. J. Zool. 75:1380-1386.

JohnsGARD, P. A. 1997. The avian brood parasites, deception at the nest. Oxford Univ. Press, New York.

Kemal, R. E., AND S. I. Rothstein. 1988. Mechanisms of avian egg recognition: adaptive responses to eggs with broken shells. Anim. Behav. 36:175183.

Lotem, A., H. NAKamura, AND A. Zahavi. 1995. Constraints on egg discrimination and cuckoo-host coevolution. Anim. Behav. 49:1185-1209.

Moksnes, A., E. Roskaft, And A. T. BraA. 1991. Rejection behavior by Common Cuckoo hosts towards artificial brood parasite eggs. Auk 108:348354.

Moksnes, A., E. Roskaft, A. T. BraA, L. Korsnes, H. M. LAMpe, And H. C. Pedersen. 1991. Behavioral responses of potential hosts towards artificial cuckoo eggs and dummies. Behaviour 116:64-89.

Moore, W. S., And V. R. DeFilippis. 1997. The window of taxonomic resolution for phylogenies based on mitochondrial cytochrome b, p. 83-119. In D. P. Mindell [ED.], Avian molecular evolution and systematics. Academic Press, San Diego, CA.

Nakamura, H., S. Kubota, And R. Suzuki. 1998. Coevolution between the Common Cuckoo and its major hosts in Japan: stable versus dynamic specialization on hosts, p. 94-112. In S. I. Rothstein and S. K. Robinson [EDS.], Parasitic birds and their hosts: studies in coevolution. Oxford Univ. Press, New York.

Parrish, J. W., J. A. PtaceK, And K. L. Will. 1984. The detection of near-ultraviolet light by nonmigratory and migratory birds. Auk 101:53-58.

PeER, B. D., AND E. K. Bollinger. 1997. Explanation for the infrequent cowbird parasitism on Common Grackles. Condor 99:151-161.

Reynolds, M. D. 1995. Yellow-billed Magpie. In A. Poole and F. Gill [EDS.], The birds of North America, No. 180. The Academy of Natural Sciences, Philadelphia, and The American Ornithologists' Union, Washington, DC.

Rohwer, S., AND C. D. Spaw. 1988. Evolutionary lag versus bill-size constraints: a comparative study of the acceptance of cowbird eggs by old hosts. Evol. Ecol. 2:27-36.

Rothstein, S. I. 1975a. An experimental and teleonomic investigation of avian brood parasitism. Condor 77:250-271.

RothSTEIN, S. I. 1975b. Evolutionary rates and host defenses against avian brood parasitism. Am. Nat. 109:161-176.

Rothstein, S. I. 1976. Experiments on defenses Cedar Waxwings use against cowbird parasitism. Auk 93:675-691.

RothSTEIN S. I. 1977. Cowbird parasitism and egg recognition of the Northern Oriole. Wilson Bull. 89: 21-32.

RothSTEIN, S. I. 1982a. Mechanisms of avian egg recognition: which egg parameters elicit responses by rejecter species? Behav. Ecol. Sociobiol. 11:229239.

RothSTEIN, S. I. 1982b. Successes and failures in avian egg and nestling recognition with comments on the utility of optimality reasoning. Am. Zool. 22: 547-560.

Rothstein, S. I. 1990. A model system for coevolution: avian brood parasitism. Annu. Rev. Ecol. Syst. 21:481-508.

RothSTEIN, S. I. 1994. A century of avifaunal change in western North America. Stud. Avian Biol. 15: 301-315.

SAVAGE, C. 1995. Bird brains: the intelligence of crows, ravens, magpies, and jays. Sierra Club, San Francisco.

Soler, J. J., J. G. Martinez, M. Soler, And A. P. MøLLER. 1999. Genetic and geographic variation in rejection behavior of cuckoo eggs by European magpie populations: an experimental test of rejecter-gene flow. Evolution 53:947-956.

Soler, M. 1990. Relationships between the Great Spotted Cuckoo (Clamator glandarius) and its corvid hosts in a recently colonized area. Ornis Scand. 21:212-223.

Soler, M., AND A. P. Møller. 1990. Duration of sympatry and coevolution between the Great Spotted Cuckoo and its magpie host. Nature 343:748-750.

Soler, M., J. J. Soler, J. G. Martinez, T. Perez-ConTRERAS, AND A. P. Møller. 1998. Micro-evolutionary change and population dynamics of a brood parasite and its primary host: the intermittent arms race hypothesis. Oecologia 117:381-390.

TAKAsU, F. 1988. Why do all host species not show defense against avian brood parasitism: evolutionary lag or equilibrium? Am. Nat. 151:193-205.

Victoria, J. K. 1972. Clutch characteristics and egg discriminative ability of the African Village Weaverbird (Ploceus cucculatus). Ibis 114:367376. 
Yom-Tov, Y. 1976. Recognition of eggs and young by the Carrion Crow (Corvus corone). Behaviour 59: 247-251.

Zink, R. M., S. Rohwer, A. V. Andreev, AND D. L.
DitTMAN. 1995. Trans-beringia comparisons of mitochondrial DNA differentiation in birds. Condor 97:639-649.

\title{
AN UNUSUAL TYPE OF SIBLING AGGRESSION IN BLACK-CROWNED NIGHT HERONS
}

\author{
Matthew J. Medeiros, Emily E. Emond and Bonnie J. Ploger \\ Department of Biology, Hamline University, 1536 Hewitt Ave., St. Paul, MN 55104, e-mail: \\ bjploger@piper.hamline.edu
}

\begin{abstract}
Sibling aggression varies with brood size, nestling age disparities, and food characteristics. We observed feeding and fighting within two broods of Black-crowned Night Herons (Nycticorax nycticor$a x)$ in Minnesota. In one nest, on two different days, a senior chick swallowed the head of its smallest sibling, immobilizing it until it seemed near death. Occasional fights also occurred in this nest only. Senior chicks in both nests gained more food than juniors. We discuss possible functions of head-swallows, including how this behavior, as well as fighting and other factors, may have enhanced the feeding advantage of seniors.
\end{abstract}

Key words: Black-crowned Night Heron, head swallows, Nycticorax nycticorax, prey size, sibling aggression, sibling competition.

Sibling aggression varies considerably among the handful of ardeid species that have been studied, from frequently fatal (siblicidal) to virtually no fights (Mock and Parker 1997). Proximate and ultimate influences on fighting in these species include brood size, disparities in sizes/ages of siblings, food scarcity, and prey size (Mock and Parker 1997). This latter, prey-size, hypothesis (Mock 1985) predicts that nestlings should fight when fed items small enough to be economically defensible, but not when fed larger items.

We report an unusual and potentially injurious form of sibling aggression in one brood of Black-crowned Night Herons (Nycticorax nycticorax). In two broods, we also investigated feeding frequency, quantity and size of prey, and whether seniors gained a feeding advantage over their junior siblings.

\section{METHODS}

Our observations took place on Egret Island Scientific and Natural Area, in Pelican Lake, near Ashby, Grant County, Minnesota, on 8 days between 6-23 June 1998 , during a larger study of sibling aggression in

\footnotetext{
${ }^{1}$ Received 20 May 1999. Accepted 17 January 2000.
}

Great Egrets (Ardea alba). A mix of Great Egrets, Double Crested Cormorants (Phalacrocorax auritus), Great Blue Herons (A. herodias), and Black-crowned Night Herons nested in stands of mostly boxelder (Acer negundo), which were separated by meadows. Night herons nested from approximately $2.5-5 \mathrm{~m}$ high in the trees.

We erected a $2.5-\mathrm{m}$ tall blind within $12 \mathrm{~m}$ of two night heron nests, which we observed with binoculars and a spotting scope. We observed nest 1 when chicks were ages $6,11-15$, and 18 days, for a total of $81 \mathrm{hr}$. We observed nest 2 for $76 \mathrm{hr}$ when chicks were ages 12-16, 19, and 24. On 3 days, we observed both nests continuously from about 05:00 to 22:00, breaking this period into approximately $8 \mathrm{hr}$ shifts by changing observers at 14:00. On other days, we observed for only one $4-8 \mathrm{hr}$ shift. Both nests contained four chicks initially, but in nest 1 a Red-tailed Hawk (Buteo jamaicensis) killed the C-chick when the brood was about 14.5 days old and the D-chick had disappeared when the brood was 18 days old.

We classified chicks as seniors ("Srs") and juniors ("Jrs") by plumage development and easily distinguishable size differences. Often we could further distinguish the youngest (D-chick) from the other (" $\mathrm{C}$ ") Jr. Brood age was the age of the oldest ("A") chick. For nest 1, we estimated the A-chick's hatching date as the day before we saw the first feed (Palmer 1962), 4 days after last seeing eggs only. We estimated A's age in nest 2 as 1 day older than in nest 1 by comparing plumage and motor-skills of the A-chicks.

Each "feed" consisted of a parent regurgitating a series of discrete boluses, no two of which were more than 10 min apart (Mock 1985). We estimated bolus lengths as percentages, to the nearest $10 \%$, of the parents' bill length from tip to eye. We standardized bolus lengths against a scale drawing of boluses relative to adult head dimensions (Ploger and Mock 1986). We used study skins at the University of Minnesota's Bell Museum to determine the bill length of seven adult Black-crowned Night Herons from Minnesota. Bill length averaged $9.6 \pm 2.6 \mathrm{~cm}$ from tip to eye. We thus 
converted bolus lengths to $\mathrm{cm}$ by estimating that each $10 \%$ of the parent's bill was $1 \mathrm{~cm}$ long. Shares of a bolus that were gained by each chick were determined by the proportion (in tenths) of the bolus that each chick received (Mock 1985). The total $\mathrm{cm}$ each chick received was calculated by multiplying its share by the bolus length.

We recorded the percentage of direct, defensible, versus indirect, indefensible boluses (Mock 1985). Parents regurgitated indirect boluses onto the nest floor, whereas direct boluses never touched the floor because chicks pulled them directly from the parent's bill. We also calculated the percentage of boluses actually monopolized by being completely consumed by only one chick. Occasional food thefts also occurred when one chick pulled food from another chick's bill.

We classified as aggressive, cases of chicks swallowing another's head or fighting. A fight consisted of a series of blows delivered until no more blows were exchanged for at least $10 \mathrm{sec}$. Blows involved one chick striking another forcefully with its beak or tightly grasping another's bill while shoving the head back one or more times (Mock and Parker 1997). A headswallow was when one chick swallowed another's head and neck to the point of wing-attachment and held the victim like this for at least $10 \mathrm{sec}$.

The nestlings also engaged in mildly aggressive interactions, which we did not call fights. Chicks sometimes faced each other while stretching their necks maximally, as is common in Great Egrets just prior to a fight (Mock and Parker 1997). Chicks frequently grasped each other's bills gently in a series of brief scissor grips until one or both sank down. We suspect that such "scissoring" was one form of what Noble et al. (1938) called "billing," although they also used this term for some behaviors that we might have classified as fights.

Statview 4.51 (Roth et al. 1995) was used for calculating descriptive statistics. Means are reported \pm SD.

\section{RESULTS}

In nest 1 , three fights occurred, and on two occasions, a $\mathrm{Sr}$ chick swallowed the head of the D-chick. No fights or head-swallows occurred in nest 2 . The fighting rate for nest 1 alone was 0.86 fights day $^{-1}$, or 0.14 fights day $^{-1}$ sibling-dyad ${ }^{-1}$, in the 3.5 days when the nest had four chicks. All aggressive interactions occurred during feeds. The first head-swallow occurred when the A-chick was 11 days old. Seven minutes after the start of a feed, after 3.5 of 5 boluses were eaten by Srs, the observer noticed a Sr swallowing the head of the D-chick. The D-chick tried to escape while its head was still in the Sr's throat. The Sr then shook D until it was motionless. D's head finally came out, slimy and wet, $2.25 \mathrm{~min}$ after the head-swallow was first noticed, 2.9 min after the $\mathrm{Sr}$ was standing over the D-chick and may have been swallowing its head. After this head-swallow, the parent brooded the chicks. The second head-swallow occurred when the A-chick was 13 days old. After the only bolus of the feed fell to the floor, a Sr swallowed the D-chick's head for about $3 \mathrm{~min}$. After its release, the D-chick squawked loudly. The chicks then pecked at the fish on the floor, which was eventually reswallowed by the parent.

The parents at nest 1 fed their chicks slightly smaller boluses than at nest $2(7 \pm 3 \mathrm{~cm}$ vs. $8 \pm 4 \mathrm{~cm}$, respectively), but delivered more boluses per feed (3.9 \pm 2.0 vs. $1.7 \pm 0.8$, respectively). These boluses averaged about $70 \%$ of the parent's bill-length. Chicks in nest 1 received fewer feeds day $^{-1}(2.3 \pm 0.58)$ than in nest $2(8.0 \pm 2.6)$, when observed all day, while both broods had four chicks. Nest 1 parents fed $37 \%$ of their boluses directly to their chicks, whereas at nest $2,59 \%$ of boluses were delivered directly. The percentage of direct boluses delivered per day was highly variable, ranging from $0-86 \%$ when chicks were 6-19 days old. The transition from indirect to direct feeds, when chicks received between $20-80 \%$ of boluses directly, was already occurring when chicks were 6 days old (at the start of this study) and continued through age 19 days. Chicks older than 19 days received all boluses directly.

The Srs in both nests received more food per feed than did their Jrs. In nest 1, Srs received $4 \pm 5 \mathrm{~cm}$ whereas Jrs received $3 \pm 7 \mathrm{~cm} \mathrm{chick}^{-1}$ feed $^{-1}$. In nest 2 , $\mathrm{Srs}$ received $5 \pm 5 \mathrm{~cm} \mathrm{chick}^{-1}$ versus $3 \pm 4 \mathrm{~cm}$ chick $^{-1}$ for Jrs. The Srs in nest 1 monopolized $34 \%$ of the boluses and Jrs monopolized $11 \%$. In Nest 2, Srs monopolized $49 \%$ of the boluses and Jrs monopolized $17 \%$. Only one of 47 boluses was stolen in nest 1 . Of the 72 boluses delivered to nest 2 , Srs stole 2 from the D-chick and attempted to steal a third one from that chick.

\section{DISCUSSION}

Head-swallows have not been reported in the literature for either night herons or other ardeids in which sibling aggression has been studied extensively. Cattle Egrets (Bubulcus ibis) occasionally show this behavior (B. Ploger, pers. observ.), but these observations remain unpublished. One possible reason why head-swallows have not been observed in well-studied Great Blue Herons and Great Egrets is that the size differences between Srs and Jrs might not exceed a certain threshold in these larger ardeids. Another possibility is that the proportionally longer bills of these large ardeids may make performing head-swallows more difficult and risky than in the shorter-billed Cattle Egrets and Black-crowned Night Herons.

Head-swallows may serve a variety of functions. Head-swallows resemble cannibalism, which has been reported occasionally in this species (Gross 1923, Beckett 1964; J. Tims, pers. comm.). Black-crowned Night Heron nestlings preying on nestling White Ibis (Eudocimus albus) sometimes swallow them only to the point of wing attachment, and successfully digest the front half of their victims before regurgitating the remains (Beckett 1964). Head-swallows may also cause non-cannibalistic siblicide by suffocating the victim. After both head-swallows that we observed, the D-chick victim appeared limp and nearly dead when it was released. Although head-swallows might occasionally result in the immediate death of the victim, a more common result might be to reduce its participation in competition for food, at least temporarily.

In our night herons, Srs in both nests averaged about 
one-third more food per chick than did Jrs. Srs gained this feeding advantage without fighting in nest 2 , and with only 0.1 fights day $^{-1} \mathrm{dyad}^{-1}$ in nest 1 . Although no data were provided, Noble et al. (1938) reported a similar pattern in which the oldest, largest chicks gained more fish than smaller nest-mates, a skew that they felt was maintained by "billing." A combination of superior motor skills in scramble competition, mild aggression such as scissoring, and occasional fights and head-swallows may all have contributed to the feeding advantage of Srs in our study.

Sibling aggression in Black-crowned Night Herons may vary among populations, possibly depending on food abundance or prey size. Such a relationship occurs in Great Blue Herons. In this species, fighting was frequent and intense in a population that fed their nestlings small prey, but in another that fed large prey, fighting rates were low (Mock et al. 1987) and similar to those that we found among nestling night herons. As in Great Blue Herons, diet and presumably prey size varies widely among different populations of Black-crowned Night Herons worldwide (Voisin 1991). Within these populations, prey sizes and intake rates vary with time of day, season, and hunting technique (Voisin 1991). In the two Black-crowned Night Heron nests that we observed, the feeding patterns that tended to differ most included the number of feeds per day, the percentage of direct feeds and percentage of boluses monopolized by seniors. Black-crowned Night Herons may be an excellent species to further explore the relationship between prey size, food amounts, and sibling aggression.

We thank R. Djupstrom and the Minnesota Department of Natural Resources for permission to work on Egret Island Scientific and Natural Area, and K. Hawes for helping us with site selection. We thank C. and W. DeVries of Indian Mounds Resort for assistance with housing and boat rental, and D. Korte for cabin maintenance and telephone use. D. Allan, T. Mengistu, N. Evelyn, and B. Fischer helped move equipment to and from the field site. K. Malody provided administrative assistance. We thank J. Tims for sharing her evidence of cannibalism in nestling night herons. The manuscript benefited from comments by D. Allan, P. Frederick, S. McGehee, W. Koenig, and an anonymous reviewer. We thank R. M. Zink and the University of Minnesota, James Ford Bell Museum of Natural History, for access to specimens of Black-crowned Night Herons. Funding was provided by the Lund Summer Research Program in Biology and a Hanna Grant, both from Hamline University.

\section{LITERATURE CITED}

BecketT, T. A., III. 1964. Black-crowned Night Heron feeding behavior. Chat 28:93-94.

Gross, A. O. 1923. The Black-crowned Night Heron (Nycticorax nycticorax naevis) of sandy neck. Auk 40:1-30.

Mock, D. W. 1985. Siblicidal brood reduction: the prey-size hypothesis. Am. Nat. 125:327-343.

Mock, D. W., T. C. Lamey, C. F. Williams, and A. Pelletier. 1987. Flexibility in the development of heron sibling aggression: an intraspecific test of the prey-size hypothesis. Anim. Behav. 35:13861393.

Mock, D. W., And G. A. Parker. 1997. The evolution of sibling rivalry. Oxford Univ. Press, Oxford.

Noble, G. K., M. Wurm, AND A. SchmidT. 1938. Social behavior of the Black-crowned Night Heron. Auk 55:7-40.

PAlmer, R. S. 1962. Handbook of North American birds. Vol. I. Yale Univ. Press, New Haven, CT.

Ploger, B. J., AND D. W. Mock. 1986. Role of sibling aggression in food distribution to nestling Cattle Egrets (Bubulcus ibis). Auk 103:768-776.

Roth, J., K. Haycock, J. Gagnon, C. Soper, and J. Caldarola. 1995. Statview. Version 4.51. Abacus Concepts, Inc., Berkeley, CA.

Voisin, C. 1991. The herons of Europe. T. \& A. D. Poyser, London. 